\title{
The biased factors of investor's behavior in stock exchange trading
}

\author{
Tri Kartika Pertiwi ${ }^{a^{*}}$, Yuniningsih Yuniningsiha and Muhadjir Anwar ${ }^{a}$
}

${ }^{a}$ Department of Management, Universitas Pembangunan Nasional Veteran Jawa Timur, Surabaya, Indonesia

CHRONICLE ABSTRACT

Article history:
Received: February 14, 2019
Received in revised format: Feb-
ruary 30, 2019
Accepted: March 6, 2019
Available online:
March 6, 2019
Keywords:
Overconfidence
Disposition Effect
Risk Tolerance
Trading Activity

\begin{abstract}
The stock exchange in Indonesia acts as a means of financial resources of business and investment for the community. Any investor needs some profit from his/her investment. However, in determining a policy for decision making, many investors do not always think, rationally. Moreover, stock trading in the stock exchange/money market faces with high uncertainty, which may create some irrational acts and leads to irrational investment decisions. This study aims to test the biased investor's behavior, such as overconfidence, disposition effect, and risk tolerance on investor's trading activities in the Indonesian Stock Exchange. To analyze the qualitative response variable in this research, the researchers considered more than two categories. Therefore, the analysis required was Multi-nominal Logistic Regression Model. Meanwhile, some investors appointed to be the subject in this research were the customers of some Securities. The survey distributed 170 questionnaires and collected 141 properly filled ones used in this research. The testing result employing simultaneous multi-nominal logistic regression show that the overall model used was quite significant. The testing conducted partially also shows that only overconfident investors were affected by trading activities. Meanwhile, the opportunity of the overconfident investor to do trading was considered to be moderate as much as 0.177 multiplied from the "infrequent" category.
\end{abstract}

\section{Introduction}

Stock market plays a crucial role in Indonesia's economic development, as one of business funding sources and investment media for the people to improve their wealth. Stock market activities can be traced from the trading volume: the high trading volume reveals vitality in the stock market. On the other hand, if the investors perform excessive trading activities, they will not get the expected returns, and it may cause large losses. Since trading activities require a high amount of investment, investors should consider the desired level of investment and the expected returns. The more active they are in trading, the less profit they may collect (Barber \& Odean, 2000). Previous studies revealed that the main cause of the stock market failure was the investors' behavior. The high uncertainty in stock trading in the financial market might frequently cause investors to make irrational decisions. This irrational investors' psychological factor is called biased investment such as overconfidence and disposition effect. This might be influenced by investors' diverse psychological aspects in perceiving the risks and returns. Risk

* Corresponding author.

E-mail address: kartika tiwi@yahoo.co.id (T. Kartika Pertiwi)

C 2019 by the authors; licensee Growing Science, Canada doi: $10.5267 /$ j.msl.2019.3.005 
tolerance in stock investment can also influence investors' trading activities. Overconfidence occurs when a person thinks that he/she is better than others. In psychology, overconfidence is associated with a person who feels has more knowledge than others, and comes to some confident that ignores other people's opinions. Consequently, such investors tend to make more mistakes in trading. An overconfident investor frequently does excessive trading (Kourtidis et al., 2011). Risk tolerance is defined as the extent to which a person is willing to take risks. In Finance, financial risk tolerance is defined as the maximum amount of uncertainty a person can tolerate in making financial decisions. Suhari et al. (2011) stated that investors with high-risk tolerance tend to make transactions or investments frequently and prefer to invest their monies on high-risk investment products. On the other hand, investors who avoid risks tend to make fewer transactions in low- risk investments. Disposition effect is an investor's behavior which tends to hold losing investment too long and to sell winning investment very quickly. Avoiding regret and seeking pride could be the reasons for the emergence of this kind of behavior. Investors with such biased behavior can be considered irrational so that in making a decision they can experience investment losses. Since 2007, investors of the Indonesian Stock Exchange have been able to perform online trading, a system in which investors can perform trading independently and monitor the stock price more easily. This condition might give negative effects on investors' psychology which can be reflected in the irrational act, over-optimistic and even sometimes emotional and panicked feelings.

Based on those problems, this study analyzes the relationship among biased overconfidence, disposition effect and risk tolerance in stock trading activities in the Indonesian Stock Exchange. This study aims to test and analyze the effect of biased behaviors- overconfidence, risk tolerance and disposition effect-on trading activities. By knowing the investors' psychological factors, investors are expected to be able to decide their trading strategies well, not merely depending on the fundamental analysis. Also, this study is also expected to be able to support academicians to combine financial and psychological analyses in identifying an anomaly in the stock exchange.

\section{Literature Review}

\subsection{Behavioral Finance Theory}

According to conventional finance theory or standard finance, investors are considered to behave irrationally in improving their wealth. Standard finance approach depends on a series of assumptions which oversimplify reality. As an example in standard finance is the view about "Homo Economicus" or rational economy human, meaning human who makes the economy decision rationally, but sometimes is influenced by emotion and psychology in decision making which may cause unpredictable or irrational behaviors (Ackert \& Deaves, 2009). A new paradigm (behavioral finance) combines cognitive psychological theory with the conventional and financial economy to explain why investors make rational financial decisions. Baker and Nofsinger (2010) studied how people behave actually in managing their finance. Furthermore, the presence of emotion and cognitive bias will influence financial decision making. Pompian (2006) defines behavioral finance as a psychological application in finance. Additionally, he divides behavioral finance into two subtopics:

1. Behavioral Finance Micro which tests behaviors or biases of individual investors, which is different from the rational behavior proposed by the classical economy. The psychological bias will influence the process of investment decision making.

2. Behavioral Finance Macro detects and describes anomalies in the Efficient Market Hypothesis.

Behavioral finance theory indeed is not as strong as standard finance, but empirical evidence cannot reject its existence. Several studies have proven that investors tend to behave irrationally, leading to the occurrence of the stock market crisis triggered by investors' panic.

\subsection{Excessive Trading Theory}

Excessive trading theory initially was proposed by Odean (1998). Theoretically, he said that overconfidence behavior depicted by high miscalibration level would lead to the investors' tendency to apply aggressive and excessive trading strategy. Eventually, it will cause poor investment performance. 
Ackert and Deaves (2009) stated that if overconfidence is connected to the trading level, overconfidence will lead to excessive trading-investor that the overconfident investor has a more flat demand curve and more responsive to prices. Several studies have also proved that overconfident investors tend to perform excessive trading (Barber \& Odean, 2001; Chen et al., 2007; Trinugroho \& Sembel, 2011). When overconfidence is connected to the investor's risk-taking, several researchers such as Barber and Odean (2001), stated that investors with overconfidence level ignore the risk and invest their money on the risky securities. They do not diversify their portfolio either and avoid buying diversified portfolio, so that it can be said they take too much risks because they are overconfident that their stocks will work well (Pompian \& Longo, 2004; Ackert \& Deaves, 2009; Pan \& M. Statman, 2012; Pan \& M. Statman, 2012). They also stated that a person with high overconfidence level would have higher risk tolerance than those with lower overconfidence level.

\subsection{Overconfidence}

Ackert and Deaves (2009) defined overconfidence as the tendency of a person to overestimate knowledge, ability and the accuracy of information that investor possesses, or the tendency to become too optimistic about the future and ability. Chen et al. (2007) suggested that overconfidence is a common behavior bias found among humans which may lead them to make cognitive mistakes. These can be reflected in the tendency to overestimate their abilities, in their success and positive results that they gain. Besides, they also think that their knowledge is accurate. According to Gervais and Odean (2001), the overconfident behavior will not make them wealthy nor increase their gains, but the process to become wealthy makes them overconfident. Additionally, according to Ackert and Deaves (2009), overconfidence appears in different forms: 1) Miscalibration. 2) Better-Than-Average Effect. 3) Illusion of Control. 4) Excessive Optimism

\subsection{Prospect Theory}

Prospect theory covers value function, decision frame, psychological accounting, probability and certainty effects.

1. Value function: People will tend to be risk-averse over gains (the value function is concave) and risk-seeking over losses (the value function is convex). It means that investors feel bad when they experience losses, and there is one origin point (zero).

2. Framing: Prospect theory predicts that preferences depend on how a problem is framed or formulated. If the reference point is formulated in such a way that the decision is considered or perceived as again, the decision maker will tend to avoid risks (risk averse). On the contrary, if the reference point is formulated to make decision resulting in losses, the decision maker will tend to take the risk (risk seeking).

3. Psychological Accounting: The decision maker will not only frame the available options but also frame the results and effects of the choices. Psychological Accounting is divided into two: minimal accounting and inclusive accounting

4. Probability: Prospect theory said that the people's tendency in decision making is the function of decision weight. The decision weight is not always connected to the size of opportunity or the frequency of occurrence.

5. Certainty Effect: Prospect theory also predicts that decision with no risk at all will be preferred than decision with a risk, even very small.

\subsection{Risk Tolerance}

Pompian (2006) asserted that, a more comprehensive financial risk hypothesizes that financial risk is a psychological phenomenon involving conditions like fear, feeling, trust and justice. Financial risk is related to the possibility of not achieving goal. Pan and Statman (2012) defined risk tolerance as a condition where a consumer is ready to take a risk when facing small gains in his business. Financial risk tolerance 
is defined as the maximum amount of uncertainty that a consumer tolerates when making financial decision, reflecting cautiousness and awareness (Kourtidis et al., 2011). Schaefer (1978) explained that investors' risk tolerance is the maximum value of investment risk which makes them comfortable to take the risk and return in that level. Several empirical studies have proved that risk taking behavior would influence trading activities. Higher tendency in risk taking is manifested through trading frequency improvement (Durand et al., 2008). Keller and Siegrist (2006) explored the relationship between market activities and risk behavior and concluded that investors who avoid risks will have lower trading activities. Moreover, risk behavior in finance reflects the willingness to invest in stock market.

\subsection{Disposition effect}

Disposition effect is an investor's decision which tends to sell the winners too soon, and to hold the losers for a long time (Nofsinger, 2011). The reason for this is an investment decision influenced by psychological behavior which tries to avoid regret and to seek pride. This disposition effect has been found by numerous researchers widely. For instance, Finnish, Israeli and Chinese investors have shown such behavior. Grinblatt and Keloharju (2001) studied all investors' trading in Finland from 1995 to 1996 and found that previous positive returns significantly improved the investors' tendency to sell their stocks. On the other side, the decline of the price significantly improved the probability that investors would keep the stocks. Based on the research background, literature review, the findings, this research considers a quantitative approach to test the relationship or the effect of independent variables on dependent variable through hypothesis testing. The proposed hypotheses are as follows:

$\mathrm{H}_{1}$ : Overconfidence influences on individual investors' trading activities.

$\mathrm{H}_{2}$ : Disposition influences on individual investors' trading activities.

$\mathrm{H}_{3}$ : Risk tolerance influences on individual investors' trading activities.

\section{Research Method}

The population in this research includes individual investors located in Surabaya. The sampling technique is used based on purposive Sampling with the criteria: 1) Investors are individuals and have become the security members of at least one year. 2) Investors invest their funds, not under any obligation. Survey method is used for data collection, by distributing questionnaires to respondents to get information directly or indirectly through mail and email. Independent variables are Overconfidence $\left(X_{l}\right)$, Disposition Effect $\left(X_{2}\right)$ dan Risk Tolerance $\left(X_{3}\right)$, which are measured by interval scale. The dependent variables are trading activities $(Y)$ which are classified into three categories: frequent, medium, infrequent. This research is applying a Multinomial Logistic Regression Model to analyze qualitative response variables with more than two categories.

\section{Findings}

\subsection{Subject General Description}

The subjects in this research are individual investors located in Surabaya. These individual investors are customers of securities in Surabaya. Securities are stock trading brokers in Indonesian Stock Exchange. The companies are Mandiri Securities, OSO Securities, Panin Securities, Reliance Securities, and Millenium Dana Tama. The respondents are the security customers with more than one-year membership and trading history. From 200 distributed questioners, 148 are returned, and only 141 were found to be eligible for the purpose of this study.

\subsection{Descriptive Statistics Based on Demography}

The respondents' gender is mostly males (79 or 56\%) aging between $21-30$ years (39\%). The education level is dominated by S1 (93 or 66\%) and their stock trading experience are between 1-5 years (106 or $75 \%)$. 


\subsection{Variable Descriptive Statistics}

To perform descriptive analysis on each variable we can categorize them based on interval scale according to the mean. This research uses three-scale categories. The formula for counting the interval scale: Interval Scale (highest score-lowest score)/ the number of scales. The interval scale is $(5-1) / 3=1.33$

To analyze the next parts, value level category for each variable following the interval scale. 1,00-2,33 =" low"; 2,34-3,66 = "sufficient"; 3,67-5,00 ="high". Based on the interval scale, the mean of overconfidence level, disposition effect and risk tolerance are 3.42, 3.18 and 3.31, respectively and they are all categorized as 'sufficient'.

\subsection{The Validity and Reliability Test Result}

Based on the validity and reliability test result, it can be concluded that all indicator items (overconfidence, disposition effect, and risk tolerance) are valid because the $r$ value (corrected item-total correlation) is bigger than the $r$ table value / the limit value (bigger than 0.164). The reliability test result indicates that all question item variables have maintained a high Alpha coefficient (above 0.6) which means that all concepts measuring each variable of the questionnaires were reliable. Therefore the items of each concept variable is reliable to use as a research instrument.

\subsection{The Analysis Results}

Partial test: This partial test is applied to find the effect of each variable (Overconfidence, Disposition effect and Risk tolerance) on trading activities. For this purpose, the Wald test is selected:. $W=\frac{\beta j}{S E(\beta j)}$.

Tabel 1

Parameter Estimation

\begin{tabular}{llccccc}
\hline Evidence & Variable & $\mathrm{B}$ & $\mathrm{SE}$ & Wald & Sig & Exp (B) \\
\hline Frequent & Intercept & 2.234 & 2.485 & .809 & .369 & \\
& $\mathrm{X}_{1}$ (Overconfidence) & .051 & .586 & .008 & .930 & 1.052 \\
& $\mathrm{X}_{2}$ (Disposition Effect) & -.182 & .462 & .155 & .694 & .834 \\
& $\mathrm{X}_{3}$ (risk tolerance) & -.014 & .395 & .001 & .972 & .986 \\
Medium & Intercept & 8.677 & 2.607 & 11.074 & .001 & \\
& $\mathrm{X}_{1}$ (Overconfidence) & -1.73 & .621 & 7.808 & .005 & .177 \\
& $\mathrm{X}_{2}$ (Disposition Effect) & -.500 & .493 & 1.028 & .311 & .607 \\
& $\mathrm{X}_{3}$ (risk tolerance) & .178 & .414 & .185 & .667 & 1.195 \\
\hline
\end{tabular}

The reference category is "infrequent."

Based on the results of Table 1, it can be concluded that:

$$
\operatorname{Ln}(\mathrm{p} \text { frequent } / \mathrm{p} \text { infrequent })=2.234+0.051 X_{1}-0.82 X_{2}-0.014 X_{3}
$$

According to Eq. (1):

1. The significance value from the Wald test is $0.930>0.05$ which means that Overconfidence variable does not affect the trading activities of frequent category compared witho the infrequent category. The overconfidence coefficient $(0.051)$ with exp value $\beta$ (1.052) means that the higher the investors' overconfidence level, the more 'frequent' trading activity.

2. The significance value of the Wald test is $0.694>0.05$. It means that the Disposition Effect variable does not have significant effect on the trading activities of 'frequent' category compared with 'infrequent' category. The disposition effect coefficient of -0.182 with exp $(\beta) 0.834$ means that by an increase on the Disposition Effect level, the investors' 'frequent' trading activity tendency will be 0.834 times the 'infrequent' category.

3. The significance value of the Wald test is $0.972>0.05$. It means that Tolerance Risk variable has no significant effect on the trading activity of 'frequent' category compared with 'infrequent' trading activity. The risk tolerance coefficient of -0.014 and $\exp (\beta) 0.986$ mean that when investor takes 
higher tolerance level, the investors' 'frequent' trading activities will be 0.986 times the 'infrequent' category.

Ln $(P$ moderate $/ P$ infrequent $)=8,677-1,734 X_{1}-0,500 X_{2}+0,178 X 3$

According to Eq. (2)

1. The significance value from the Wald test is $0.005<0.05$ which means that Overconfidence variable has a significant effect on the trading activities of 'moderate' category compared with the infrequent category. The overconfidence coefficient of -1.734 with exp value $\beta(0.177)$ means that when investor has a higher overconfidence level, their 'moderate' trading activity tendency will be 0.177 times the 'infrequent' trading activities.

2. The significance value of the Wald test is $0.311>0.05$, which means that the Disposition Effect variable has no significant effect on the trading activities of 'moderate' category compared with 'infrequent' category. The disposition effect coefficient of -0.500 with exp $(\beta) 0.607$ means that an increase on the Disposition Effect level will increase the investors' 'moderate' trading activity tendency by 0.607 times compared with the 'infrequent' category.

3. The significance value of the Wald test is $0.667>0.05$, which indicates that Tolerance Risk variable has no significant effect on the trading activity of 'moderate' category compared with 'infrequent' category.

\subsection{Simultaneous Test}

This test is carried out to find whether an independent variable has a significant effect on trading activities or not. The ' $\mathrm{G}$ ' test is used for this purpose:

$$
G=-2 \ln \left(\frac{l(l \omega)}{l(l \beta)}\right)
$$

where $\mathrm{L}(\omega)$ = maximum value likelihood without certain predictor variable. This ' $\mathrm{G}$ ' Statistics follows the Chi-Square with free 'p' degree.

Table 2

Information Fitting Model

\begin{tabular}{lcccc}
\hline Model & $\begin{array}{c}\text { Model fitting criteria } \\
-2 \text { Log Likelihood }\end{array}$ & Chi-Square & $\begin{array}{c}\text { Likelihood Ratio Tests } \\
\mathrm{df}\end{array}$ & Sig. \\
\hline Intercept Only & 245.684 & & & \\
Final & 210.000 & 35.683 & 6 & .000 \\
\hline
\end{tabular}

Table 2 indicates that the final model maintains Chi-square of 35,683 with $\mathrm{df}=6$ and $\mathrm{P}$ value $=0.000$, which means that the independent variables have a significant effect on the dependent variable, simultaneously.

\subsection{The goodness of Fit Model Test}

This test is used to see how data homogeneity of independent variables can explain the data homogeneity of the dependent variable. This test can be seen from the Pseudo R-Square given in Table 3.

\section{Table 3}

Pseudo R-Square

\begin{tabular}{ll} 
Cox and Snell & .224 \\
Nagelkerke & .267 \\
McFadden & .139 \\
\hline
\end{tabular}

Pseudo R-Square on Negelkerke indicates the value of 0.267 which means that overconfidence, disposition Effect and risk tolerance can explain the investors' stock trading activities $26.7 \%$ through a logistic regression model. 


\section{Discussion and conclusion}

A multinominal logistic regression test has been applied to examine the effect of Overconfidence $\left(\mathrm{X}_{1}\right)$, Disposition effect $\left(\mathrm{X}_{2}\right)$ and risk tolerance $\left(\mathrm{X}_{3}\right)$ variables on trading activities $(\mathrm{Y})$. The trading activities (Y) are divided into three categories: frequent (completing at least one trading transaction in a week), moderate (completing at least one trading transaction in a month), infrequent (completing at least one trading transaction in a year). 'infrequent' category is selected to be a reference category which will be used as a comparator in this research analysis. The multinomial logistic regression analysis in Eq. (1) indicates that overconfidence had no effect on trading activities of 'frequent' category compared with 'infrequent' category. Positive overconfidence coefficient has indicated that the higher the investors' overconfidence level, the more trading activities they perform. Glaser and Weber (2007) stated that the higher the investors' confidence level, the bigger the trading volume that they perform. In other words, the higher their overconfidence level, the more transactions in the stock market. Gervais and Odean (2001) found that overconfident investor will perform aggressive trading which would increase the trading volume. Disposition effect variable does not affect the trading activities of 'frequent' category compared with 'infrequent' category. This result is not in line with Shefrin and Statman (1985) who argued that the tendency to avoid regret and seek pride could persuade the investors to sell winners quickly and hold losers for longer time. Risk tolerance variable does not affect the trading activities of 'frequent' category compared with 'infrequent' category. The results have shown a negative coefficient, meaning that the higher the investors' risk tolerance, the less trading activities they perform. This result is different from Durand's results which stated that a higher tendency in risk-taking was manifested in the increased trading frequency (Durand et al., 2008). This research result supports Keller and Siegrist (2006) who stated that investors who avoid risks would perform less trading activities. Moreover, risk-taking behavior in finance reflects the willingness to invest in the stock market. Multinominal logistic regression analysis from Eq. (2) has indicated that only overconfidence variable affects trading activities. Overconfidence variable has had a negative effect on trading activities, which means that the higher the investors' overconfidence level, the lower the trading activities they perform. This result is in contrast with Glaser and Weber (2007) and Gervais and Odean (2001) who found that the overconfident investors could perform aggressive trading which will increase trading volume. In this research, through the responses from individual investors of security members in Surabaya, investors tend to perform trading activities in 'moderate' category (at least once a month). Additionally, the investors involved in this research has experienced from 1 to 5 years which was considered as having little experience and consequently they did not perform trading activities frequently. The disposition effect variable analysis does not influence the investors' trading activities of 'moderate' category compared with 'infrequent' category. Risk tolerance variable does not effect on trading activities of 'moderate' category compared with 'infrequent' category.

\section{Suggestions}

Based on the data analysis results, several suggestions are proposed for further research:

1. To identify variables which influence trading activities, it is suggested to use or add another variable such as 'herding' that is investors' behavior following other investors.

2. Overconfidence level can be measured by using another instruments.

\section{References}

Ackert, L., \& Deaves, R. (2009). Behavioral finance: Psychology, decision-making, and markets: Cengage Learning.

Baker, H. K., \& Nofsinger, J. R. (2010). Behavioral finance: investors, corporations, and markets (Vol. 6): John Wiley \& Sons. 
Barber, B. M., \& Odean, T. (2000). Trading is hazardous to your wealth: The common stock investment performance of individual investors. The Journal of Finance, 55(2), 773-806.

Barber, B. M., \& Odean, T. (2001). Boys will be boys: Gender, overconfidence, and common stock investment. The quarterly journal of economics, 116(1), 261-292.

Chen, G., Kim, K. A., Nofsinger, J. R., \& Rui, O. M. (2007). Trading performance, disposition effect, overconfidence, representativeness bias, and experience of emerging market investors. Journal of Behavioral Decision Making, 20(4), 425-451.

Durand, R. B., Newby, R., \& Sanghani, J. (2008). An intimate portrait of the individual investor. The Journal of Behavioral Finance, 9(4), 193-208.

Gervais, S., \& Odean, T. (2001). Learning to be overconfident. Review of Financial Studies, 14(1), 1-27.

Glaser, M., \& Weber, M. (2007). Overconfidence and trading volume. The Geneva Risk and Insurance Review, 32(1), 1-36.

Grinblatt, M., \& Keloharju, M. (2001). What makes investors trade? The journal of Finance, 56(2), 589616.

Keller, C., \& Siegrist, M. (2006). Investing in stocks: The influence of financial risk attitude and valuesrelated money and stock market attitudes. Journal of Economic Psychology, 27(2), 285-303.

Kourtidis, D., Šević, Ž., \& Chatzoglou, P. (2011). Investors' trading activity: A behavioural perspective and empirical results. The Journal of Socio-Economics, 40(5), 548-557.

Nofsinger, J. R. (2011). The psychology of investing: Prentice Hall 4th edn. Boston, MA.

Odean, T. (1998). Do investors trade too much? Available at SSRN 94143.

Pan, C., \& Statman, M. (2012). Questionnaires of risk tolerance, regret, overconfidence, and other investor propensities. SCU Leavey School of Business Research Paper(10-05).

Pan, C. H., \& Statman, M. (2012). Questionnaires of risk tolerance, regret, overconfidence, and other investor propensities. The Journal of Investment Consulting, 13(1), 54-62.

Pompian, M. M. (2006). Behavioral Finance and Wealth Management: How to Build Optimal Portfolios That Account for Investor Biases ([Wiley Finance]: Wiley.

Pompian, M. M., \& Longo, J. M. (2004). A new paradigm for practical application of behavioral finance: creating investment programs based on personality type and gender to produce better investment outcomes. The Journal of Wealth Management, 7(2), 9-15.

Schaefer, R. E. (1978). What are We Talking about when We Talk about" Risk"?. Institute for Applied systems Analysis.

Shefrin, H., \& Statman, M. (1985). The disposition to sell winners too early and ride losers too long: Theory and evidence. The Journal of Finance, 40(3), 777-790.

Suhari, E., Trinugroho, I., Rahardian, R., \& Ivada, W. (2011). Psychographic and Investor Behavior in Indonesia. Interdisciplinary Journal of Contemporary Research in Business, 2(11).

Trinugroho, I., \& Sembel, R. (2011). Overconfidence and excessive trading behavior: An experimental study. International Journal of Business and Management, 6(7).

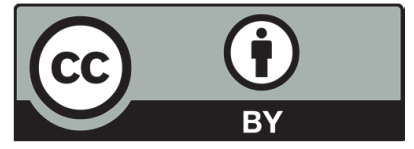

(C) 2019 by the authors; licensee Growing Science, Canada. This is an open access article distributed under the terms and conditions of the Creative Commons Attribution (CCBY) license (http://creativecommons.org/licenses/by/4.0/). 